OnLine Journal of Biological Sciences 12 (1): 34-37, 2012

ISSN 1608-4217

(C) 2012 J.A. Batista-Da-Silva, This open access article is distributed under a Creative Commons Attribution

(CC-BY) 3.0 license

\title{
Phoretic Association and Facultative Parasitoidism Between Megaselia scalaris and Blowflies, Under Natural Conditions
}

\author{
Jose Antonio Batista-Da-Silva \\ Department of Medical and Forensic Entomology, \\ Laboratory of Leishmaniasis Transmitters, \\ Institute Oswaldo Cruz-IOC/FIOCRUZ, \\ RJ, Brazil, 4365, Manguinhos-RJ, 04060, Brazil
}

\begin{abstract}
Problem statement: This is the first time that a phoretic association and facultative parasitoidism between Megaselia scalaris and blowflies (Diptera: Calliphoridae) has been reported under natural conditions. Approach: All fly specimens were collected in the mangrove swamp in Itaborai, RJ, Brazil. Results: A total of 291 flies were collected belonging to four (04) species of the family Calliphoridae: Chrysomya megacephala (Fabricius) (280), Cochliomyia macellaria (Fabricius) (05), Chrysomya albiceps (Wiedemann) (05), Chrysomya putoria (Wiedemann) (01) and all had third instar larvae of $M$. scalaris or had eggs of the Phoridae attached to their bodies. The specimens were separated and the flies, larvae and eggs were then identified. Conclusion/Recommendations: The highest prevalence for the capture of these flies was in the spring. From the study performed we conclude that $M$. scalaris acting as a facultative parasitoid of insects could be of great significance showing the need to screen laboratories more securely against invasions by $M$. scalaris.
\end{abstract}

Key words: APA guapi-mirim, diptera, mangrove swamps, reported finding, natural conditions

\section{INTRODUCTION}

Phoridae are small flies and have been described on exposed human corpses (Greenberg and Wells, 1998). About 225 genera and over 2,500 species of Phoridae are known in the world fauna (Borgmeier and Prado, 1975) and the genus Megaselia Rondani includes around 1,400 species distributed in the tropics and subtropics (Costa et al., 2007).

Megaselia scalaris can be a parasitoid of insects of agronomic, veterinary and medical importance (Ulloa and Hernandes, 1981; Rocha et al., 1984; Harrison and Gardner, 1991; Costa et al., 2007). This study was carried out to report the occurrence of the scuttle fly, $M$. scalaris as a parasitoid of blowflies and also the occurrence of blowflies as phoretic of $M$. scalaris under natural conditions in Itaboraí, Brazil.

\section{MATERIALS AND METHODS}

All specimens were collected in a small part of the mangrove swamp in Guapi-Mirim Environmental Protection Area, in Itaboraí (RJ), which has a total area of $138.25 \mathrm{~km}^{2}$ with $61.80 \mathrm{~km}^{2}$ of mangrove swamps. Its geographical location is S $22^{\circ} 39^{\prime} 30^{\prime \prime}-$ $22^{\circ} 46^{\prime} 50^{\prime \prime}$ latitude and W $42^{\circ} 57^{\prime} 00^{\prime \prime}-43^{\circ} 06^{\prime} 40^{\prime \prime}$ longitude. To trap and collect the flies, four $35 \mathrm{~cm}$ high, $15 \mathrm{~cm}$ diameter plastic traps placed $100 \mathrm{~m}$ apart were used. (trap models were according to Ferreira (1978) and modified according to Batista-Da-Silva et al., 2010). The traps were suspended at a height of $1.20 \mathrm{~m}$ above the ground for a period of $48 \mathrm{~h}$. and the bait used was based on fish (sardine) in decomposition (methods according to Batista-Da-Silva et al., 2010). When setting up the traps, the bait was transported in closed containers thus avoiding any possible contamination.

At the collection time, all specimens were killed by asphyxiation with $70 \%$ ethanol inside the traps and all specimens were then put into plastic pots containing $70 \%$ ethanol for transportation to the Laboratory of Leishmaniasis Transmitters (Department of Medical and Forensic Entomology) at the Institute Oswaldo Cruz-IOC/FIOCRUZ, RJ, Brazil. At the laboratory the flies were separated and then identified using a stereoscopic microscope $(80 \mathrm{X})$ and the dichotomous keys for families and species according to Mello (2003); Disney and Ashmole (2004); Disney (2005) ;the eggs according to Greenberg and Kunich (2002); the larvae according to Sukontason et al. (2002). The flies parasitized were dissected and observed internally using a stereoscopic microscope. 
OnLine J. Biol. Sci., 12 (1): 34-37, 2012

Table 1: Total number and percentage of flies parasitized or with eggs of the Megaselia scalaris attached to their bodies and caught during the different seasons of the year, in a mangrove swamp, Itaboraí, Rio de Janeiro, Brazil

\begin{tabular}{|c|c|c|c|c|c|c|c|c|c|c|}
\hline \multicolumn{11}{|c|}{ Parasitized species caught through the year in a mangrove swamp } \\
\hline \multirow[b]{2}{*}{ Species } & \multicolumn{2}{|c|}{ Spring } & \multicolumn{2}{|c|}{ Summer } & \multicolumn{2}{|c|}{ Autumn } & \multicolumn{2}{|c|}{ Winter } & \multicolumn{2}{|c|}{ Total } \\
\hline & $\mathrm{N}$ & $(\%)$ & $\mathrm{N}$ & $(\%)$ & $\mathrm{N}$ & $(\%)$ & $\mathrm{N}$ & $(\%)$ & $\mathrm{N}$ & $(\%)$ \\
\hline Chrysomya albiceps & 02 & 0.72 & 01 & 16.67 & 02 & 33.34 & 00 & 0.00 & 05 & 1.72 \\
\hline Chrysomya megacephala & 272 & 97.49 & 04 & 66.66 & 04 & 66.66 & 00 & 0.00 & 280 & 96.22 \\
\hline Chrysomya putoria & 00 & 0.00 & 01 & 16.67 & 00 & 0.00 & 00 & 0.00 & 01 & 0.34 \\
\hline Cochliomyia macellaria & 05 & 1.79 & 00 & 0.00 & 00 & 0.00 & 00 & 0.00 & 05 & 1.72 \\
\hline Total & 279 & 100.00 & 06 & 100.00 & 06 & 100.00 & 00 & 0.00 & 291 & 100.00 \\
\hline
\end{tabular}

\section{RESULTS}

A total of 291 flies were captured belonging to four (04) species of the family Calliphoridae (Table 1): Chrysomya megacephala (Fabricius) (280), Cochliomyia macellaria (Fabricius) (05), Chrysomya albiceps (Wiedemann) (05), Chrysomya putoria (Wiedemann) (01) and all had third instar larvae of $M$. scalaris (Fig. 1) or had eggs of the Phoridae (Fig. 2) attached to their bodies. The highest prevalence for the capture of these flies was in the spring (279).

The parasitized flies had part of his muscles and internal organs destroyed. The mean temperature during the collection was $31.63 \pm 4.0^{\circ} \mathrm{C}$ and relative humidity was $64.53 \pm 10.9 \%$. All Phoridae adults found inside the traps were identified as $M$. scalaris and the species C. megacephala showed higher occurrence of the third instar larvae of $M$. scalaris or eggs of the Phoridae parasitoid attached to their bodies.

\section{DISCUSSION}

The species $M$. scalaris have a wide geographical distribution (Borgmeier, 1968; Costa et al., 2007) and according to Manix (1964) can be found in the tropics and subtropics.

The occurrence of this species infesting and laying eggs, under natural conditions, on the indigenous screwworm, C. macellaria and blowfly Chrysomya species of the family Calliphoridae has not been reported until now. The occurrence of this infestation may be related to the substrate (sardine in decomposition) used to attract the muscoid, which may have also attracted the species $M$. scalaris, who have part of their life cycle in decomposed organic matter. All adult Phoridae found inside the trap belonged to the species $M$. scalaris demonstrating an absence of competition with other Phoridae species. The identification of the adult is one of the easiest and most secure ways to identify small flies (Disney and Munk, 2004) and this fact confirmed that the eggs and larvae found on the Calliphoridae, belonged to the species $M$. scalaris.

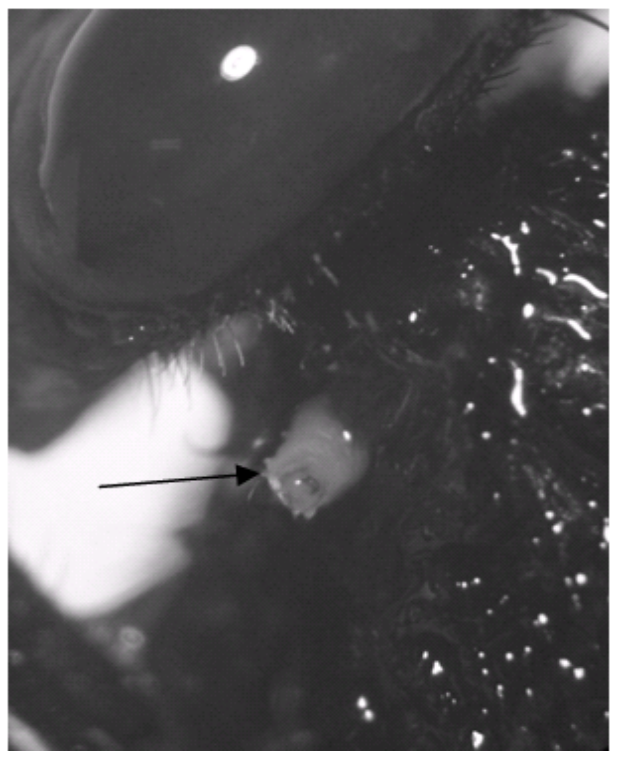

Fig. 1: Chrysomya megacephala with third instar larvae of Megaselia scalaris

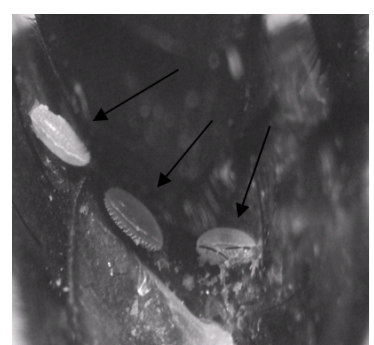

(a)

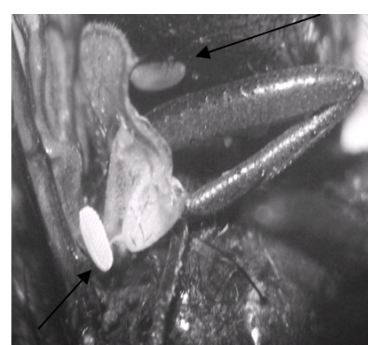

(b)
Fig. 2: Chrysomya megacephala (a) and Chrysomya putoria (b) with eggs of the parasitoid Megaselia scalaris attached to their bodies

According to Manix (1964) their life cycle is approximately 18 days for males and 20 days for females under $28^{\circ} \mathrm{C}$ (seven days in three larval instars). Although the traps used were exposed for $48 \mathrm{~h}$ periods, the larvae of $M$. scalaris had probably already 
parasitized the family Calliphoridae flies before entering the traps. Spring and summer are the seasons with the highest tides in the mangrove swamp, with a maximum variation of $1.40 \mathrm{~m}$, twice a day. The spring also represents the end of diapause for some species of the family Calliphoridae, which are well adapted to mangroves swamp. According to Greenberg and Kunich (2002) the pupae of this family can resist drowning for a period of four days. The abundance of Calliphoridae in mangrove swamps is higher in spring than in the other seasons. Coincidentally the period of highest occurrence of Calliphoridae acting as phoretic or suffering parasitoidism by $M$. scalaris larvae is also in the spring, which may indicate the synchronism of the life cycle of $M$. scalaris in the spring when the tides are highest. $M$. scalaris feeds on insects of many orders and families and included in the Coleoptera order are: Cicindellidae (Kirk-Spriggs and Marais, 1999), Scarabaeidae and Tenebrionidae (Batist, 2002). Also in the order Diptera $M$. scalaris feeds on Drosophilidae and Muscidae (Zwart et al., 2005). Also M. scalaris has been associated with the laboratory cockroach (Dictyoptera) (Robinson, 1975; Miller, 1979), Gryllidae (Batist, 2002) and colonies of Triatoma brasiliensis (Costa et al., 2007).

Megaselia scalaris infests cultures that are inadequately protected causing facultative parasitoidism (Disney, 2008).

\section{CONCLUSION}

The knowledge of the biological cycle of necrophagous entomofauna is one of the bases of forensic entomology and many of these insects are breed in laboratories and the occurrence of M. scalaris, as reported in this study could be of great significance showing the need to screen laboratories more securely against invasions by $M$. scalaris.

\section{ACKNOWLEDGMENT}

To Fundação Oswaldo Cruz and the Prefeitura Municipal de Itaboraí for providing the material resources, to the board of the Área de Proteção Ambiental de Guapi-Mirim (APA Guapi-Mirim) that granted permission to collect the specimens and David Graham Straker for the English revision.

\section{REFERENCES}

Batist, P.D., 2002. Bijdrage tot de studie van Megaselia scalaris (Loew), 1866 (Diptera, Phoridae), een niet zo fraaie aanwinst voor de Belgische fauna. Bull. Inst. R. Sci. Nat. Belg. Biol., 72: 143-48.
Batista-Da-Silva, J.A., G.E. Moya-Borja and M.M.C. Queiroz, 2010. Occurrence and seasonality of muscoid (Diptera, Calliphoridae) of public health importance in Itaboraí (RJ), Brazil. EntomoBrasilis, $\quad 3$ 16-21. www.periodico.ebras.bio.br/ojs/index.php/ebras/art icle/viewFile/69/90

Borgmeier, T., 1968. A catalogue of the Phoridae of the world (Diptera, Phoridae). Stud. Entomol., 11: 1367.

Borgmeier, T. and A.P. Prado, 1975. New or littleknown neotropical phorid flies, with description of a eight new genera (Diptera, Phoridae). Stud. Entomol., 18: 3-90.

Costa, J., C.E. Almeida, G.M. Esperanca, N. Morales and J.R.S. Mallet et al., 2007. First record of Megaselia scalaris (Loew) (Diptera: Phoridae) infesting laboratory colonies of Triatoma brasiliensis Neiva (Hemiptera: Reduviidae). Neotrop. Entomol., 36: 987-989. DOI: 10.1590/S1519-566X2007000600026

Disney, R.H.L. and N.P. Ashmole, 2004. Scuttle flies (Diptera: Phoridae) of the remote Atlantic islands of the Southern Hemisphere. Fragm. Faun., 47: 127-138.

Disney, R.H.L. and T. Munk, 2004. Potential use of Braconidae (Hymenoptera) in forensic cases. Med. Vet. Entomol., 18: 442-444. DOI: 10.1111/j.0269283X.2004.00521.X

Disney, R.H.L., 2005. Phoridae (Diptera) of Madagascar and nearby islands. Stud. Dipterol., 12: 139-77.

Disney, R.H.L., 2008. Natural history of the scuttle fly, Megaselia scalaris. Annu. Rev. Entomol., 53: 3960. DOI: 10.1146/annurev.ento.53.103106.093415

Ferreira, M.J.M., 1978. Sinantropia de dípteros muscóides de Curitiba, Paraná. I: Calliphoridae. Rev. Bras. Biol., 38: 445-454.

Greenberg, B. and J.D. Wells, 1998. Forensic use of Megaselia abdita and $M$. scalaris (Phoridae: Diptera): case studies, development rates and egg structure. J. Med. Entomol., 35: 205-209.

Greenberg, B. and J.C. Kunich, 2002. Entomology and the Law: Flies as Forensic Indicators. 1st Edn., Cambridge University Press, Cambridge, ISBN-10: 0521809150, pp: 306.

Harrison, R.D. and W.A. Gardner, 1991. Parasitism of the pecan weevil (Coleoptera: Curculionidae) by Megaselia scalaris (Diptera: Phoridae). J. Entomol. Sci., 26: 301-302.

Kirk-Spriggs, A.H. and E. Marais, 1999. Megaselia scalaris (Loew) (Diptera: Phoridae): A potential pest problem in field prepared insect specimens. Cimbebasia, 15: 163-64. 
Manix, F., 1964. The genetics of Megaselia scalaris Loew (Phoridae): A new type of sex determination in diptera. Am. Natur., 98: 415-430.

Mello, R.P., 2003. Chave para identificação das formas adultas das espécies da família Calliphoridae (Diptera, Brachycera, Cyclorrhapha) encontradas no Brasil. Entomol. Vect., 10: 255-268.

Miller, P.L., 1979. Intraspecific phorid phoresy. Entomol. Mon. Mag., 114: 211-14.

Rocha, U.F., M. Belo, J.R. Morais, A. Sogorb and A. Baruch, 1984. Ecologia de carrapatos. VI: Influência da umidade ambiente sobre a invasão de fêmeas de Boophilus microplus (Canestrini) (Acari, Ixodidae) por larvas de Megaselia scalaris loew (Diptera, Phoridae) e sobre a prolificidade desses artropodes. Naturalia, 9: 93-100.
Robinson, W.H., 1975. Megaselia scalaris (Diptera: Phoridae) associated with laboratory cockroach colonies. Proc. Entomol. Soc. Washington., 77: 384-390.

Sukontason, K.L., K. Sukontason, S. Lertthamnongtham and N. Boonchu, 2002. Surface Ultrastructure of Third-instar Megaselia scalaris (Diptera: Phoridae). Mem. Inst. Oswaldo Cruz., 97: 663-665. PMID: 12219132

Ulloa, P.C.D. and A.M.R.D. Hernandez, 1981. Biología y control natural de Peridroma saucia, plaga de la flor de la curuba. Rev. Col. Entomol., 7: 47-53.

Zwart, P., R.H.L. Disney, P. de Batist and F. Mutschmann, 2005. The phorid "scuttlefly" (Megaselia scalaris) a threat to zoological collections and especially to amphibians? Zool. Med. BVZS., 5: 27-30. 